\title{
Endoscopic full-thickness resection in a recurrent perianastomotic esophagojejunal cancer followed by fully covered metal stent placement for lumen occlusion
}

An 82-year-old man underwent total gastrectomy for a gastric cancer located in close proximity to the cardia (G2, PT1b,pN2 R0 M0). A follow-up gastroscopy 1 year later showed a flat, slightly elevated lesion in the esophagojejunal anastomosis. The lesion was $15 \mathrm{~mm}$ in diameter and had an irregular pit pattern (• Fig.1). Biopsy were performed and histologic examination revealed recurrence of the cancer.

After multidisciplinary consensus, endoscopic management was preferred due to both the high risk associated with major invasive surgical re-treatment and the age of the patient.

Endoscopic full-thickness resection (EFTR) using the FTRD System (Ovesco Endoscopy AG, Tübingen, Germany) was performed. The EFTR device consists of a transparent cap, on which both a 14-mm over-the-scope clip (OTSC) and an integrated oval snare are preloaded. The procedure was performed under deep sedation and using carbon dioxide insufflation.

The lesion was identified endoscopically, marked circumferentially, and grasped into the cap. The OTSC was deployed and the lesion was resected. Repeat endoscopy showed a satisfactory full-thickness resection but an occlusion of the jejunal lumen was observed at the site of the OTSC. Thus, under fluoroscopic guidance, through a 0.035 -inch guidewire, a fully covered metal stent $(6 \mathrm{~cm}$ in length, $28 \mathrm{~mm}$ in diameter) was released, bypassing the occluded section at the site of the OTSC ( $\vee$ Video 1$)$. The patient was discharged after 2 days of clinical follow-up, and a semisolid diet was suggested.

The stent was removed 3 weeks later. Gastroscopy showed a regular scar ( Fig. 2) without residual lumen stenosis.

Histologic analysis confirmed the diagnosis of a recurrent signet cell adenocarcinoma (T1b, R0).

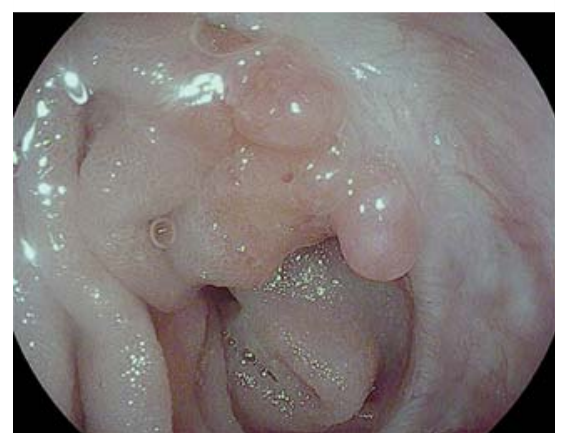

-Fig. 1 Recurrent cancer in the esophagojejunal anastomosis.

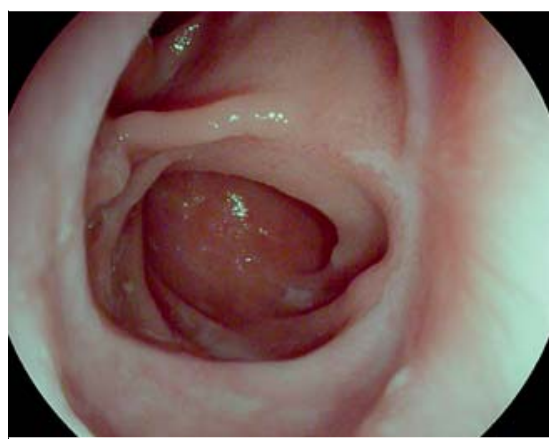

- Fig. 2 Follow-up gastroscopy showed a regular scar.

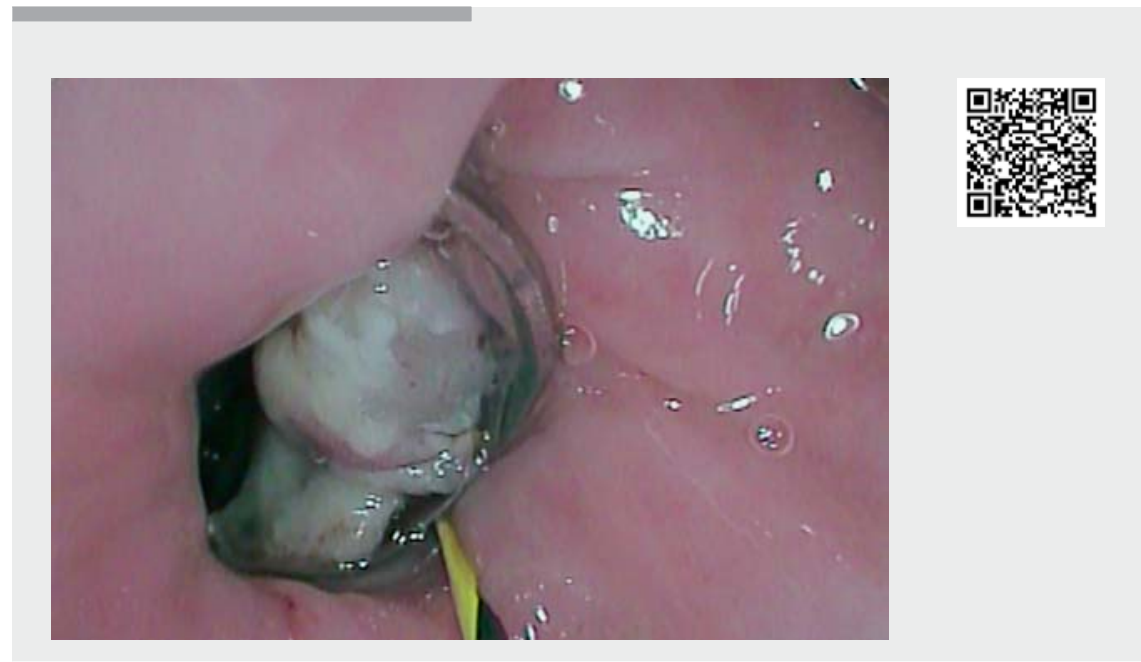

$\checkmark$ Video 1 Endoscopic full-thickness resection in a recurrent perianastomotic esophagojejunal cancer followed by fully covered metal stent placement for lumen occlusion.

To the best of our knowledge, this is the first published case in which EFTR has been used in a recurrent perianastomotic cancer in the upper gastrointestinal tract [1]. Moreover, stent placement was effective in resolving stenosis when EFTR was complicated by lumen occlusion.

Endoscopy_UCTN_Code_TTT_1AO_2AN

\section{Competing interests}

The authors declare that they have no conflict of interest.

The authors

Angelo Caruso, Salvatore Russo, Giuseppe Grande, Flavia Pigò, Santi Mangiafico, Helga Bertani, Rita Conigliaro

Azienda Ospedaliero-Universitaria di Modena, Ospedale Civile di Baggiovara, Endoscopia Digestiva, Baggiovara, Italy 
Corresponding author

\section{Angelo Caruso, MD}

Endoscopia Digestiva, Azienda OspedalieroUniversitaria di Modena Ospedale Civile di Baggiovara, Via Pietro Giardini 1355, 41126 Baggiovara, Italy

Phone: 0039-059-3961220

Fax: +39-059-3961216

angelocaruso@hotmail.it

\section{Reference}

[1] Bauder M, Schmidt A, Caca K. Endoscopic full-thickness resection of duodenal lesions - a retrospective analysis of 20 FTRD cases. United European Gastroenterol J 2018; 6: 1015-1021

Bibliography

DOI https://doi.org/10.1055/a-1113-7001

Published online: 18.3.2020

Endoscopy 2020; 52: E337-E338

(c) Georg Thieme Verlag KG

Stuttgart · New York

ISSN 0013-726X
ENDOSCOPY E-VIDEOS

https://eref.thieme.de/e-videos

回回 Endoscopy E-Videos is a free access online section, reporting 国: on interesting cases and new techniques in gastroenterological endoscopy. All papers include a high quality video and all contributions are freely accessible online.

This section has its own submission website at

https://mc.manuscriptcentral.com/e-videos 